\title{
Obesity and genetic polymorphism of ERCC2 and ERCC4 as modifiers of risk of breast cancer
}

\author{
Sang-Ah Lee ${ }^{1 *}$, Kyoung-Mu Lee ${ }^{1 *}$, \\ Woong-Yang Park ${ }^{2}$, Bongcheol Kim ${ }^{4}$, \\ Jinwu Nam ${ }^{4}$, Keun-Young Yoo ${ }^{1}$, \\ Dong-Young Noh ${ }^{3}$, Sei-Hyun $\mathrm{Ahn}^{5}$, \\ Ari Hirvonen ${ }^{6}$ and Daehee Kang ${ }^{1,7}$ \\ ${ }^{1}$ Department of Preventive Medicine \\ ${ }^{2}$ Department of Biochemistry \\ ${ }^{3}$ Department of General Surgery \\ Seoul National University College of Medicine \\ Seoul 110-749, Korea \\ ${ }^{4}$ Pan Genomics Co., Ltd., Seoul, Korea \\ ${ }^{5}$ Department of Surgery \\ Ulsan University College of Medicine \\ Seoul 138-736, Korea \\ ${ }^{6}$ Department of Industrial Hygiene and Toxicology \\ Institute of Occupational Health \\ 00250 Helsinki, Finland \\ ${ }^{7}$ Corresponding author: Tel, 82-2-740-8326; \\ Fax, 82-2-747-4830; E-mail, dhkang@snu.ac.kr \\ ${ }^{*}$ Theses authors contributed equally to this work.
}

Accepted 22 February 2005

Abbreviations: $\mathrm{BMI}$, body mass index; $\mathrm{Cl}$, confidence interval; NER, nucleotide excision repair; OR, odd ratio

\begin{abstract}
To evaluate the relationship of genetic polymorphisms of ERCC2 and ERCC4 genes, both involved in nucleotide excision repair (NER), and the risk of breast cancer, a hospital-based case-control study was conducted in Korea. Histologically confirmed breast cancer cases $(n=574)$ and controls $(n=502)$ with no present or previous history of cancer were recruited from three teaching hospitals in Seoul during 1995-2001. Information on selected characteristics was collected by interviewed questionnaire. ERCC2 $\mathrm{Asp}^{312} \mathrm{Asn}$ (G>A) was genotyped by single-base extension assay and ERCC4 Ser ${ }^{835} \mathrm{Ser}(\mathrm{T}>\mathrm{C})$ by dynamic allelespecific hybridization system. Although no significant association was observed between the genetic polymorphisms and the risk of breast cancer, women with both ERCC2 A allele- and ERCC4 C allele-containing genotypes showed a 2.6 -fold risk (95\% Cl: $1.02-6.48)$ of breast cancer compared to
\end{abstract}

women concurrently carrying the ERCC2 GG and ERCC4 TT genotypes. The breast cancer risk increased as the number of "at risk" genotypes increased with a borderline significance $(P$ for trend $=0.07$ ). Interactive effect was also observed between ERCC4 genotype and body mass idnex (BMI) for the breast cancer risk; the ERCC4 C allele containing genotypes posed a 1.7 -fold $(95 \%$ Cl: $0.96-2.93)$ breast cancer risk in obese women $\left(B M I>25 \mathrm{~kg} / \mathrm{m}^{2}\right)$ with a borderline significance. Our finding suggests that the combined effect of ERCC2 $\mathrm{Asp}^{312} \mathrm{Asn}$ and ERCC4 Ser ${ }^{835}$ Ser genotypes might be associated with breast cancer risk in Korean women.

Keywords: body mass index; breast neoplasms; DNA repair enzymes; ERCC4 protein

\section{Introduction}

Breast cancer is the second common malignancy diagnosed among Korean women and the incidence is increasing continuously (National Statistical Office of Korea, 1998). Although a substantial proportion of breast cancer cases are explained by well-established risk factors (i.e., later age of first birth, nulliparity and first-degree family history of breast cancer) (Madigan et al., 1995), the reason for the observed worldwide increase in breast cancer incidence is still largely unknown.

Because of the importance of maintaining genomic integrity in carcinogenesis (Seo et al., 2004), genes coding for DNA repair molecules have been proposed as candidates for modifiers of individual susceptibility to breast cancer (Shields et al., 1991). This view is supported by previous epidemiological studies suggesting that a combination of genetic polymorphism of DNA repair genes and exposure to genotoxic agents may contribute to breast cancer development (Patel et al., 1997; Goode et al., 2002; Smith et al., 2003).

The nucleotide excision repair (NER) pathway repairs bulky lesions such as pyrimidine dimmers, photoproducts, large chemical adducts, and cross-links (Wood et al., 1997). The NER pathway involves at least four steps: (a) damage recognition by a complex of bound protein XPC; (b) unwinding of the DNA by the TFIIH complex that includes ERCC2; (c) removal of the damaged single-stranded fragment by molecules including an ERCC1-ERCC4 complex; and (d) synthesis by DNA polymerase (Friedberg et al., 2001).

The ERCC2 protein possesses both single-strand DNA-dependent ATPase and 5'-3' DNA helicase ac- 
tivities and is thought to participate in DNA unwinding during the NER. To date, several genetic polymorphisms of ERCC2 gene have been found, i.e., in exon 6 (22541: $\left.\operatorname{Arg}{ }^{156} \mathrm{Arg}, \mathrm{A}>\mathrm{C}\right)$, exon 10 (23591: Asp ${ }^{312}$ Asn, G $>A$ ), and exon 23 (35931: Lys $^{751} \mathrm{G} \ln , A$ $>C$ ) (Winsey et al., 2000). Although both $\mathrm{Asp}^{312}$ Asn and Lys ${ }^{751} \mathrm{GIn}$ are nonsynonymous and related to functional activities (Tang et al., 2002), Asp ${ }^{312}$ Asn locus was selected in this study because $A s{ }^{312} A s n$ polymorphisms has been shown to affect smoking related lung cancer (Hou et al., 2002; Zhou et al., 2002) and breast cancer risk whereas Lys ${ }^{751} \mathrm{GIn}$ is not associated with breast cancer risk and $\mathrm{Asp}^{312} \mathrm{Asn}$ and Lys ${ }^{751} \mathrm{GIn}$ in the strong linkage disequilibrium $(P<$ .0001) (Justenhoven et al., 2004).

The ERCC4 has an important role of removing the damaged single-stranded fragment by constructing an ERCC1-ERCC4 complex. Several genetic polymorphisms of ERCC4 gene have been found, including those in $5^{\prime}$ noncoding region (g2063: $T>A)$, exon 8 (1224: $\operatorname{Arg}^{415} \mathrm{G} \ln , \quad G>A$; 1727: Arg $^{546}$ Thr, $G>C$ ), and exon 11 (2117: $\| e^{706}$ Thr, $T>$ C; 2505: Ser ${ }^{835}$ Ser, T>C; 2624: Glu ${ }^{875}$ Gly, A $>$ G) (Fan et al., 1999). A few studies on association between ERCC4 genotypes and cancer proneness was conducted: Ser ${ }^{835}$ Ser and melanoma skin cancer (Winsey et al., 2000) and $\mathrm{Arg}^{415} \mathrm{GIn}$ and breast cancer (Smith et al., 2003). Since the genotype of frequency of $\mathrm{G} / \mathrm{n} / \mathrm{G} \ln$ genotype of codon 415 was very rare $(3 \%)$ and there was no significant association with breast cancer in Caucasian women, Ser ${ }^{835}$ Ser locus of exon 11 was selected in this study.

Our previous studies suggest that XRCC1 $\mathrm{Arg}^{399} \mathrm{GIn}$ and hOGG1 $\mathrm{Ser}^{326}$ Cys genotypes may be associated with the risk of breast cancer (Kim et al., 2002; Choi et al., 2003). Here we extended the study to examine the association between the ERCC2 Asp ${ }^{312}$ Asn $(G>A)$ and ERCC4 $\operatorname{Ser}^{835} \operatorname{Ser}(T>C)$ genotypes and breast cancer risk. These genes and loci were selected on the basis of their functional significance and known allele frequencies (Fan et al., 1999; Winsey et al., 2000; Hou et al., 2002; Tang et al., 2002; Zhou et al., 2002).

\section{Subjects and Methods}

\section{Study subjects}

The study subjects were recruited from patients admitted to the department of surgery at three teaching hospitals located in Seoul (Seoul National University Hospital, Borame Hospital, and Asan Medical Center) from March 1995 to January 2001 (Lee et al., 2004). Eligible subjects consisted of a series of histologically confirmed incident breast cancer patients $(n=577)$ and non-cancer controls $(n=507)$ from whom blood samples were available. After excluding subjects with previous history of cancer, hysterectomy or oophorectomy, the final study population consisted of 574 cases and 502 controls. The study design was approved by the Committee on Human Research of
Seoul National University Hospital. The study subjects gave informed consent prior to participation in the study. Informed consent was obtained from all participants at the time of blood withdrawal.

Information on demographic characteristics, education, marital status, family history of breast cancer, reproductive factors and menstruation, and life style habits (including smoking and alcohol consumption) was collected using a questionnaire administered by trained interviewers.

\section{Genotyping Methods}

DNA was isolated using standard methods from whole blood drawn into $10 \mathrm{ml}$ heparinized tubes and stored in $-70^{\circ} \mathrm{C}$ until use.

The ERCC2 Asp ${ }^{312}$ Asn genotype was determined by single base extension assay. Polymerase chain reaction (PCR) product was obtained using $500 \mathrm{nM}$ of oligonucleotide primers (P1: 5'-CCC AGC TCA TCT CTC CGC AGG ATC A-3' and P2: 5'-GGG AGG CGG GAA AGG GAC TG-5') in a total volume of $20 \mu \mathrm{l}$. The amplification conditions were: initial denaturation at $95^{\circ} \mathrm{C}$ for $5 \mathrm{~min}$ followed by 35 cycles of $30 \mathrm{~s}$ at $94^{\circ} \mathrm{C}$ and $180 \mathrm{~s}$ at $72^{\circ} \mathrm{C}$.

Primer extension was performed by combining $1 \mu \mathrm{l}$ of exonuclease I and alkaline phosphatase treated PCR product with $5 \mu$ single base extension kit, 0.15 pmol extension primer (5'-TGG CCA ACC CCG TGC TGC CC-3') and $3 \mu$ l water. The reaction mixture was incubated at $94^{\circ} \mathrm{C}$ for 2 min prior to PCR of 25 cycles of $95^{\circ} \mathrm{C}$ for $5 \mathrm{~s}, 50^{\circ} \mathrm{C}$ for $5 \mathrm{~s}$, and $60^{\circ} \mathrm{C}$ for $5 \mathrm{~s}$. Aliquots of $1 \mu \mathrm{l}$ SNaPshot product and $9 \mu \mathrm{Hi}$-Di formamide, were combined in a 96-well 3100 optical microamp plate, which was loaded onto a 3100 DNA sequencer (Applied Biosystems, Foster city, CA). Reactions were electrophoresed on a $36-\mathrm{cm}$ capillary array at $60^{\circ} \mathrm{C}$ by using POP4 polymer, dye set "E" and Genescan run module "SNP36POP4_default." Electrophoresis data were processed by Genescan Analysis version 3.7 (Applied Biosystems, Foster city, CA).

The ERCC4 $\mathrm{Ser}^{835}$ Ser genotype was determined by dynamic allele-specific hybridization system (DASH, Hybaid). The 61 bp PCR product was obtained from about $10 \mathrm{ng}$ DNA using the following oligonucleotide primers P1: 5'-GGC GAC AGC ACT GGC CAT TAC-3' (20 pmol) and P2: biotin-labeled 5'-ATT ATA CTT CTC TGA CTC GG-3' (4 pmol) (Bioneer: Seoul, Korea) in $20 \mu$ volume PCR reaction. The genotype data could be achieved for $67 \%$ of the subjects for ERCC 4 and of $93 \%$ the subjects for ERCC2. The main reasons for the low success rate were too low amount of DNA and/or unsuccessful PCR amplification.

\section{Statistical analysis}

Chi-square test and Fisher's exact test were used to test whether observed genotype data were consistent with Hardy-Weinberg equilibrium and to compare the allele frequencies between cases and controls. Odds ratios (ORs) and $95 \%$ confidence intervals (Cls) were 
calculated by unconditional logistic regression model. The ORs were adjusted for age, body mass index (BMI), lifetime estrogen exposure, education and family history of breast cancer. To test the effect of combined genotype, we also carried out a likelihood ratio test for the multiple genotypes grouped by the ERCC2 $\mathrm{Asp}^{312} \mathrm{Asn}$ and ERCC4 $\mathrm{Ser}^{835}$ Ser polymorphisms. Lifetime estrogen exposure was calculated for premenopausal women by subtracting the menarcheal age and child number and multiplied by 280/365 from the age at interview, and for postmenopausal women subtracting the menarcheal age and child number $\times 280 / 365$ from the age at menopause (Huang et al., 1999). To increase the statistical power, the respective genotypes were divided into two groups in the statistical analyses. All analyses were carried out with the SPSS (version 10.0) statistical software package.

\section{Results and Discussion}

The mean age was 47.9 in cases and 46.9 in controls. Higher education (at and over high school; OR $=2.0,95 \% \mathrm{Cl}: 1.47-2.67)$, BMI $\left(\geq 25 \mathrm{~kg} / \mathrm{m}^{2} ; \mathrm{OR}=\right.$ $1.5,95 \% \mathrm{Cl}: 1.07-2.02)$, and family history of breast cancer $(\mathrm{OR}=2.4,95 \% \mathrm{Cl}$ : 1.34-4.40) were significantly associated with breast cancer risk (Table 1). There was a significant trend of increased risk of the lifetime estrogen exposure increased $(P$ for trend $<0.001$, Table 1).

The frequency of ERCC2 A allele in the present Asian controls $(5.3 \%)$ was drastically lower than that previous reported in Caucasians (33-44\%) (Wensey et al., 2000; Tomescu et al., 2001; Vogel et al., 2001; Hou et al., 2002), whereas the frequency of ERCC4 $\mathrm{C}$ allele $(23 \%)$ was similar to the frequencies found in UK (23\%) (Wensey et al., 2000) and USA (33\%) (Fan et al., 1999). When the ERCC2 and ERCC4 genotypes were studied separately, no significant overall associations with the risk of breast cancer were seen (Table 2). No association between the ERCC2 $\mathrm{Asp}^{312}$ Asn polymorphisms and breast cancer observed in this study is consistent with a previous study (Tang et al., 2002), but not consistent with a recent larger study (Justenhoven et al., 2004). However, interactive effect was observed between ERCC4 and $\mathrm{BMI}$ for the breast cancer risk: the ERCC4 C allele containing genotypes posed a 1.7 -fold $(95 \% \mathrm{Cl}$ : $0.96-2.93$ ) breast cancer risk in obese women (BMI $>25 \mathrm{~kg} / \mathrm{m}^{2}$ ) with a borderline significance. There was no association between ERCC4 genetic polymorphism and $\mathrm{BMI}(\mathrm{OR}=1.2,95 \% \mathrm{Cl}$ : $0.89-1.84$, data not shown).

Although there is no previous data available on the potential association between ERCC2 genetic polymorphism and breast cancer risk, the present negative finding is similar to the result reported by Fraglia et al. that the ERCC2 genotypes did not significantly affect the formation of 4-aminobiphenyl-DNA adducts in breast tissue (Fraglia et al., 2003). Although the odds ratio was just statistically borderline significant, the effects of ERCC4 $\mathrm{C}$ allele containing genotypes on the risk of breast cancer in women with higher BMI might be explained by the fact that a higher BMI may be associated with higher levels of lipophilic aromatic compounds, stored in breast adipose tissue, leading to a continuous exposure to DNA-damaging agents (Gorlewska-Roberts et al., 2002). Deficient

Table 1. Selected characteristics of study subjects.

\begin{tabular}{|c|c|c|c|}
\hline & Cases $(n=574)$ & Controls $(n=502)$ & $\mathrm{OR}^{*}(95 \% \mathrm{Cl})$ \\
\hline Mean age (yr) & $47.9 \pm 10.55$ & $46.9 \pm 13.93$ & $P=0.180$ \\
\hline \multicolumn{4}{|l|}{ BMI } \\
\hline$<25 \mathrm{~kg} / \mathrm{m}^{2}$ & $437(77.1)$ & $408(81.4)$ & 1.0 \\
\hline$\geq 25 \mathrm{~kg} / \mathrm{m}^{2}$ & $130(22.9)$ & $93(18.6)$ & $1.5(1.07-2.02)$ \\
\hline \multicolumn{4}{|l|}{ Family history of breast cancer } \\
\hline No & $528(92.0)$ & $485(96.6)$ & 1.0 \\
\hline Yes & $46(8.0)$ & $17(3.4)$ & $2.4(1.34-4.40)$ \\
\hline \multicolumn{4}{|l|}{ Education } \\
\hline Less than high-school & $188(32.9)$ & $211(42.4)$ & 1.0 \\
\hline At and over high-school & $384(67.1)$ & $287(57.6)$ & $2.0(1.47-2.67)$ \\
\hline \multicolumn{4}{|l|}{ Lifetime estrogen exposure } \\
\hline$<20 \mathrm{yr}$ & $69(12.1)$ & $136(27.5)$ & 1.0 \\
\hline $20-30 \mathrm{yr}$ & $306(53.5)$ & $215(43.5)$ & $3.9(2.67-5.84)$ \\
\hline \multirow[t]{2}{*}{$>30 \mathrm{yr}$} & $197(34.4)$ & $143(28.9)$ & $4.2(2.59-6.69)$ \\
\hline & & & $P_{\text {for trend }}<0.001$ \\
\hline
\end{tabular}

*Adjusted for age, BMI $\left(<25 \mathrm{~kg} / \mathrm{m}^{2}\right.$ vs. $\left.\geq 25 \mathrm{~kg} / \mathrm{m}^{2}\right)$, lifetime estrogen exposure $(<20 \mathrm{yr}, 20-30 \mathrm{yr}, \geq 30 \mathrm{yr}$ ), education (less than high school vs. at and over high school), and family history of breast cancer. 
Table 2. ERCC2 Asp ${ }^{312} \mathrm{Asn}$, and ERCC4 $\mathrm{Ser}^{835} \mathrm{Ser}$ and risk of breast cancer development.

\begin{tabular}{|c|c|c|c|c|c|c|c|c|c|}
\hline & \multicolumn{3}{|c|}{ All women } & \multicolumn{3}{|c|}{ Premenopausal women } & \multicolumn{3}{|c|}{ Postmenopausal women } \\
\hline & $\begin{array}{l}\text { Cases } \\
\text { N }(\%)\end{array}$ & $\begin{array}{l}\text { Controls } \\
N(\%)\end{array}$ & $\begin{array}{c}\mathrm{OR}^{*} \\
(95 \% \quad \mathrm{Cl})\end{array}$ & $\begin{array}{l}\text { Cases } \\
\text { N (\%) }\end{array}$ & $\begin{array}{l}\text { Controls } \\
N(\%)\end{array}$ & $\begin{array}{c}\mathrm{OR}^{*} \\
(95 \% \quad \mathrm{Cl})\end{array}$ & $\begin{array}{l}\text { Cases } \\
N(\%)\end{array}$ & $\begin{array}{l}\text { Controls } \\
N(\%)\end{array}$ & $\begin{array}{c}\mathrm{OR}^{*} \\
(95 \% \quad \mathrm{Cl})\end{array}$ \\
\hline \multicolumn{10}{|l|}{ ERCC2 } \\
\hline GG & $475(90.0)$ & $401(90.1)$ & 1.0 & $300(89.0)$ & $238(89.1)$ & 1.0 & $175(91.6)$ & $160(91.4)$ & 1.0 \\
\hline GA & $50(9.5)$ & $41(9.2)$ & $1.2(0.74-1.85)$ & $35(10.4)$ & $26(9.8)$ & $1.3(0.72-2.30)$ & $15(7.9)$ & $15(8.6)$ & $0.9(0.43-2.03)$ \\
\hline AA & $3(0.5)$ & $3(0.7)$ & $0.8(0.12-3.23)$ & $2(0.6)$ & $3(1.1)$ & $0.4(0.06-2.26)$ & $1(0.5)$ & - & - \\
\hline$G A+A A$ & $53(10.0)$ & $44(9.9)$ & $1.1(0.72-1.75)$ & $37(11.0)$ & $28(10.9)$ & $1.1(0.66-2.01)$ & $16(8.4)$ & $15(8.6)$ & $1.0(0.47-2.16)$ \\
\hline Total & $528(100)$ & $445(100)$ & & $337(100)$ & $267(100)$ & & $191(100)$ & $175(100)$ & \\
\hline \multicolumn{10}{|l|}{ ERCC4 } \\
\hline TT & $211(54.7)$ & $194(57.7)$ & 1.0 & $141(56.2)$ & $110(57.6)$ & 1.0 & $70(51.7)$ & $82(57.3)$ & 1.0 \\
\hline TC & $157(40.7)$ & $129(38.4)$ & $1.1(0.85-1.63)$ & $98(39.0)$ & $73(38.2)$ & $1.1(0.77-1.81)$ & $59(43.7)$ & $56(39.2)$ & $1.1(0.68-1.92)$ \\
\hline CC & $18(4.6)$ & $13(3.9)$ & $1.3(0.57-2.74)$ & $12(4.8)$ & $8(4.2)$ & $1.1(0.43-2.99)$ & $6(4.4)$ & $5(3.5)$ & $1.4(0.36-5.26)$ \\
\hline $\mathrm{TC}+\mathrm{CC}$ & $175(45.3)$ & $142(42.3)$ & $1.2(0.87-1.62)$ & $110(43.8)$ & 81 (42.4) & $1.1(0.78-1.77)$ & 65 (48.1) & $61(42.7)$ & $1.2(0.70-1.92)$ \\
\hline Total & $386(100)$ & $336(100)$ & & $251(100)$ & $191(100)$ & & $135(100)$ & $143(100)$ & \\
\hline
\end{tabular}

*Adjusted for age, BMI $\left(<25 \mathrm{~kg} / \mathrm{m}^{2}\right.$ vs. $\left.\geq 25 \mathrm{~kg} / \mathrm{m}^{2}\right)$, lifetime estrogen exposure $(<20 \mathrm{yr}, 20-30 \mathrm{yr}, \geq 30 \mathrm{yr}$ ), education (less than high school vs. at and over high school), and family history of breast cancer.

Table 3. Association between ERCC4 genotype and BMI for the risk of breast cancer.

\begin{tabular}{ccccccc}
\hline $\begin{array}{c}\mathrm{BMI} \\
\left(\mathrm{kg} / \mathrm{m}^{2}\right)\end{array}$ & ERCC4 & $\begin{array}{c}\text { Cases } \\
\mathrm{N}(\%)\end{array}$ & \multicolumn{2}{c}{$\begin{array}{c}\text { Controls } \\
\mathrm{N}(\%)\end{array}$} & $\begin{array}{c}\mathrm{OR}^{*} \\
(95 \% \mathrm{Cl})\end{array}$ \\
\hline$<25$ & TT & $169(44.2)$ & $159(47.3)$ & 1.0 & \\
$\mathrm{~kg} / \mathrm{m}^{2}$ & $\mathrm{CT} / \mathrm{CC}$ & 128 & $(33.5)$ & $116(34.5)$ & 1.1 & $(0.77-1.52)$ \\
$\geq 25$ & TT & $40(10.5)$ & $35(10.4)$ & 1.2 & $(0.72-2.10)$ \\
$\mathrm{kg} / \mathrm{m}^{2}$ & CT $/ \mathrm{CC}$ & $45(11.8)$ & 26 & $(7.7)$ & 1.7 & $(0.96-2.93)$
\end{tabular}

*Adjusted for age, lifetime estrogen exposure $(<20 \mathrm{yr}, 20-30 \mathrm{yr}, \geq$ $30 \mathrm{yr}$ ), education (less than high school vs. at and over high school), and family history of breast cancer.

DNA repair may contribute to the accumulation of damaged DNA unrepaired in both lymphocyte and target tissue.

When the combined genotype effects were examined, women with concurrent presence of ERCC2 A allele and ERCC4 $\mathrm{C}$ allele containing genotypes showed a 2.6 -fold $(95 \% \mathrm{Cl}: 1.02-6.48)$ risk of breast cancer compared to those with ERCC2 GG and ERCC4 TT genotype combination (Table 4). The risk of breast cancer increased with the number of "at risk" genotypes, however it was only borderline significance $\left(P_{\text {for }}\right.$ trend $\left.=0.07\right)$. This gene-gene interaction may be explained by that ERCC2 opens up the DNA structure and ERCC4 forms a complex with ERCC1 that incises DNA at the 5' side of a bulky adduct lesion (Friedberg et al., 2001). Genetic variants of ERCC2 and ERCC4 may have a combined effect on breast cancer risk since both ERCC2 and ERCC4 are involved in nucleotide excision repair. In conclusion,
Table 4. Combined effect of ERCC2 and ERCC4 for the risk of breast cancer.

\begin{tabular}{|c|c|c|c|}
\hline$E R C C 2$ and ERCC4 & $\begin{array}{l}\text { Cases } \\
N(\%)\end{array}$ & $\begin{array}{l}\text { Controls } \\
\text { N (\%) }\end{array}$ & $\mathrm{OR}^{*}(95 \% \mathrm{Cl})$ \\
\hline \multicolumn{4}{|l|}{ All women } \\
\hline GG and TT & $171(50.3)$ & $148(53.0)$ & 1.0 \\
\hline $\mathrm{GA} / \mathrm{AA}$ or $\mathrm{TC} / \mathrm{CC}$ & $150(44.1)$ & $123(44.1)$ & $1.1(0.75-1.48)$ \\
\hline \multirow[t]{2}{*}{$\mathrm{GA} / \mathrm{AA}$ and $\mathrm{TC} / \mathrm{CC}$} & $19(5.6)$ & $8(2.9)$ & $2.6(1.02-6.48)$ \\
\hline & & & $P_{\text {for trend }}=0.07$ \\
\hline \multicolumn{4}{|l|}{ Premenopausal } \\
\hline GG and TT & $118(52.2)$ & $89(52.4)$ & 1.0 \\
\hline GA/AA or $\mathrm{TC} / \mathrm{CC}$ & $94(41.6)$ & $76(44.7)$ & $1.0(0.62-1.49)$ \\
\hline \multirow[t]{2}{*}{$\mathrm{GA} / \mathrm{AA}$ and $\mathrm{TC} / \mathrm{CC}$} & $14(6.2)$ & $5(2.9)$ & $2.8(0.83-9.11)$ \\
\hline & & & $P$ for trend $=0.08$ \\
\hline \multicolumn{4}{|l|}{ Postmenopausal } \\
\hline GG and TT & $53(46.5)$ & $57(53.3)$ & 1.0 \\
\hline GA/AA or $\mathrm{TC} / \mathrm{CC}$ & $56(49.1)$ & 47 (43.9) & $1.1(0.66-2.06)$ \\
\hline \multirow[t]{2}{*}{$\mathrm{GA} / \mathrm{AA}$ and $\mathrm{TC} / \mathrm{CC}$} & $5(4.4)$ & $3(2.8)$ & $2.3(0.19-10.4)$ \\
\hline & & & $P_{\text {for } \text { trend }}=0.53$ \\
\hline
\end{tabular}

*Adjusted for age, BMI $\left(<25 \mathrm{~kg} / \mathrm{m}^{2}\right.$ vs. $\left.\geq 25 \mathrm{~kg} / \mathrm{m}^{2}\right)$, lifetime estrogen exposure $(<20 \mathrm{yr}, 20-30 \mathrm{yr}, \geq 30 \mathrm{yr}$ ), education (less than high school vs. at and over high school), and family history of breast cancer.

our finding suggests that the combined effect of ERCC2 Asp ${ }^{312}$ Asn and ERCC4 Ser ${ }^{835}$ Ser genotypes may be associated with breast cancer risk. However, a larger study combined with other SNP loci of functional significance (e.g., ERCC2 Lys ${ }^{751} \mathrm{GIn}$, ERCC4 5' noncoding region, etc.) is warranted in the future. 


\section{References}

Choi JY, Hamajima N, Tajima K, Yoo KY, Yoon KS, Park SK, Kim SU, Lee KM, Noh DY, Ahn SH, Choe KJ, Han W, Hirvonen A, Kang D. hOGG1 Ser326Cys polymorphism and breast cancer risk among Asian women. Breast Cancer Res Treat 2003;79:59-62

Fan F, Liu CP, Tavare S, Arnheim N. Polymorphisms in the human DNA repair gene XPF. Mutat Res 1999;406:115-20

Faraglia B, Chen SY, Gammon MD, Zhang YJ, Teitelbaum SL, Neugut Al, Ahsan H, Garbowski GC, Hibshoosh H, Lin D, Kadlubar FF, Santella RM. Evaluation of 4-aminobiphenyl-DNA adducts in human breast cancer: the influence of tobacco smoke. Carcinogenesis 2003;24:719-25

Friedberg EC. How nucleotide excision repair protects against cancer. Nat Rev Cancer 2001;1:22-33

Goode EL, Ulrich CM, Potter JD. Polymorphisms in DNA repair genes and associations with cancer risk. Cancer Epidemiol. Biomarker Prev 2002;11:1513-30

Gorlewska-Roberts K, Green B, Fares M, Ambrosone CB, Kadlubar FF. Carcinogen-DNA adducts in human breast epithelial cells. Environ Mol Mutagen 2002;39:184-92

Hou SM, Falt S, Angelini S, Yang K, Nyberg F, Lambert $B$, Hemminki K. The XPD variant alleles are associated with increased aromatic DNA adduct level and lung cancer risk. Carcinogenesis 2002;23:599-603

Huang CS, Chern HD, Chang KJ, Cheng CW, Hsu SM, Shen $\mathrm{CY}$. Breast cancer risk associated with genotype polymorphism of the estrogen-metabolizing genes CYP17, CYP1A1, and COMT: A multigenic study on cancer susceptibility. Cancer Res 1999;59:4870-5

Justenhoven C, Hamann U, Pesch B, Harth V, Rabstein S, Baisch C, Vollmert C, Illig T, Ko YD, Bruning T, Brauch $H$. ERCC2 genotypes and a corresponding haplotype are linked with breast cancer risk in a German population. Cancer Epidemiol Biomarkers Prev 2004;13:2059-64

Kim SU, Park SK, Yoo KY, Yoon KS, Choi JY, Seo JS, Park WY, Kim JH, Noh DY, Ahn SH, Choe KJ, Strickland PT, Hirvonen A, Kang D. XRCC1 genetic polymorphism and breast cancer risk. Phamacogenetics 2002;12:335-8

Lee SA, Kang D, Nishio H, Lee MJ, Kim DH, Han W, Yoo $\mathrm{KY}$, Ahn SH, Choe KJ, Hirvonen A, Noh DY. Methylenetetrahygrofolate reductase polymorphism, diet, and breast cancer in Korean women. Exp Mol Med 2004;36:116-21
Madigan MO, Ziegler RG, Benichou J, Byme C, Hoover RN. Proportion of breast cancer cases in the United States explained by well-established risk factors. J Natl Cancer Inst 1995;87:1681-5

National Statistical Office of Korea. Annual Report on the Cause of Death Statistics, Korea, 1998.

Patel RK, Trivedi AH, Arora DC, Bhatavdekar JM, Patel DD. DNA repair proficiency in breast cancer patents and their first-degree relatives. Int J Cancer 1997;73:20-4

Seo YR, Jung HJ. The potential roles of p53 tumor suppressor in nucleotide excision repair (NER) and base excision repair (BER). Exp Mol Med 2004;36:505-9

Shields PG, Harris CC. Molecular epidemiology and the genetics of environmental cancer. JAMA 1991;266:681-7

Smith TR, Levine EA, Perrier ND, Miller MS, Freimanis RI, Lohman K, Case LD, Xu J, Mohrenweiser HW, Hu JJ. DNArepair genetic polymorphisms and breast cancer risk.Cancer Epidemiol Biomarkers Prev 2003;12(11 Pt 1):1200-4

Smith TR, Miller MS, Lohman KK, Case LD, Hu JJ. DNA damage and breast cancer risk. Carcinogenesis 2003;24:883-9

Tang D. Cho S, Rundle A, Chen S, Philips D, Jingzhi Z, Hsu Y, Schnabel F, Estabrook A, Perera FP. Polymorphisms in the DNA repair enzyme XPD are associated with increased levels of PAH-DNA adducts in a case-control study of breast cancer. Breast Cancer Res Treat 2002;75:159-66

Tomescu D, Kavanagh G, Ha T, Campbell H, Melton DW. Nucleotide excision repair gene XPD polymorphisms and genetic predisposition to melanoma. Carcinogenesis 2001;22: 403-8

Vogel U, Hedayati M, Dybdahl M, Grossman L, Nexo BA. Polymorphisms of the DNA repair gene XPD: correlations with risk of basal cell carcinoma revisited. Carcinogenesis 2001;22:899-904

Winsey SL, Halder NA, Marsh HP, Bunce M, Marshall BS, Harris AL. A variant within the DNA repair gene XRCC3 is associated with the development of melanoma skin cancer. Cancer Res 2000;60:5612-6

Wood RD. Nucleotide excision repair in mammalian cells. J Biol Chem 1997;272:23465-8

Zhou W, Liu G, Miller SW, Thurston SW, Xu LL, Wain JC, Lynch TJ, Su L, Christiani DC. Gene-environment interaction for the ERCC2 polymorphisms and cumulative cigarette smoking exposure in lung cancer. Cancer Res 2002;62: 1377-81 